Article

\title{
Genetic Evaluation of Growth Traits in New Synthetic Rabbit Line in Egypt
}

\author{
El-Sayed Abdel-Kafy*, Amira S. El-Deighadi, Hoda M. Shabaan, Wael H. A. Ali, Zain El-Abdeen A. Sabra,
} A. Farid

How to cite this paper: Abdel-Kafy, E.S., S. El-Deighadi, A., M. Shabaan, H., H. A. Ali, W., A. Sabra, Z. E.-A., \& Farid, A. (2021). Genetic evaluation for growth traits in new synthetic rabbit line in Egypt. Open Journal of Agricultural Research, 1(2). Retrieved from https://www.scipublications.com/journal/index.php/ojar/article/view/119
Animal Production Research Institute (APRI), Agriculture Research Center, Dokki, Cairo, Egypt

*Correspondence: sayedabdkaffy@yahoo.com
Received: August 2, 2021

Accepted: September 16, 2021

Published: September 17, 2021

Copyright:@ 2021by the authors. Submitted for possible open access publication under the terms and conditions of the Creative Commons Attribution (CC BY) license (http://creativecommons.org/licenses /by/4.0/).

\begin{abstract}
Native Middle Egypt Rabbit breed (NMER) was crossbred with Gaint Flander rabbits to create a synthetic line. This study was aimed to evaluate the genetic estimates of this synthetic line with comparing to the purebreds. A crossbreeding was carried out by mating bucks of Gaint Flander $(\mathrm{G})$ with does of NMER $(\mathrm{N})$ to get $\mathrm{F} 1\left(1 / 2 \mathrm{~N} 1 \frac{1}{2} \mathrm{G}\right)$, then does and bucks of F1 were mated to get $\mathrm{F} 2$ $(1 / 2 \mathrm{~N} 1 / 2 \mathrm{G}) 2$, followed by two generations of inter se-mating to get a new synthetic line is called Egyline with a genetic structure of $((1 / 2 \mathrm{~N} 1 / 2 \mathrm{G}) 2) 2$. Heritability estimates for body weights were generally moderate and ranged from 0.10 to 0.24 , while the estimates of heritability for growth rate were low and moderate and ranging from 0.01 to 0.23 . Common little effects of body weight were large as weaning $(0.61)$, then declined gradually as the rabbit grew older. Also, the same trends were observed for relative growth rate (RGR). The direct additive effects were positive and highly significant for all body weights at different ages, favoring Gaint Flander and heavier comparing with NMER rabbits. Most relative growth rates during different intervals were non-significant. Gaint Flander was highly significant and heavier in maternal additive effects it in different weeks of age comparing with NMER rabbits. Direct heterosis effect for most bodyweight was positive and highly significant, and percentages of direct heterosis increased generally with the advance of age. Maternal heterosis for growth rates from 5 to 6,8 to 10, and 10 to 12 week was positive, only. Direct recombination effects for most bodyweight were positive and highly significantly exclude weight at 5 and 6 weeks. It is concluded that a new synesthetic line (Egy-line) has proven its superiority and performance well in all different body weights and most growth rates compared to other parents and crossbreds.
\end{abstract}

Keywords: Rabbit; direct and maternal additive effects; direct and maternal heterosis effects; synthetic line; Egypt;

\section{Introduction}

An Egyptian domestic rabbit is found in rural areas of Delta, Middle and Upper Egypt [1]. In the middle of last century, Ministry of Agriculture researchers tried to improve native Egyptian rabbits(Baladi rabbit) by crossbreeding for several generations of Baladi with the Flemish Giant(FG)[2]. This trial produced Baladi Red (BR), Baladi Black (BB) and Baladi White (BW) with $1 / 8$ Baladi and7/8 FG. The BR, BB and Gabali breeds used in crossing with V-line and developed by selection of synthetic lines were named APRI, Alexantria, and Moshtohor lines [3], receptively. The main interest in crossbreeding is to profit from their complementarity and the effect of heterosis [4]. Direct and maternal additive effects and direct heterosis on post-weaning body weight traits were significant and favored V-line rabbits compared to Baladi Red [5]. Also, direct and maternal genetic effects were higher in V-line than Gabali rabbits for most post-weaning growth traits [6]. The superiority of the Gabali breed in growth was over the V-line could be because of the 
complementary the superiority that exhibited by the V-line in prolificacy [7]. This complementarity was beneficial for the cross between Gabali and V-line and for the global performance of the line synthesized; Moshtohor line [27].

Advantage of the effect of heterosis requires a complex scheme through maintenance and selection of the pure stocks that had seemed too complex to set up in Egypt where the structures were not enough developed to accompany this process. [8] reported that the establishment of rabbit farms had a popular target in Egypt that caused spreading the foreign breeds and lines; New Zealand White (NZW), California (Cal), V-Line and Hyplus for their fast productive and reproductive performance, but small holders discovered these rabbits are not suitable with small-scale production system. In 2009, Animal Production Research Institute (APRI) established rabbit herd nucleus from three governorates in Middle Egypt and the collected rabbits were named NMER as abbreviation for Native Middle Egypt Rabbit breed [9]. NMER seemed low sensitive to the negative effects of summer conditions in their reproductive traits than the local lines and foreign breeds rose in Egypt, but the weight of the young and mature in NMER is still low[9]. We choice improve the NMER rabbits by to create a synthetic line to profit from their genetic potential. So, this study aimed to evaluate the genetic estimates of a new synthetic line with comparing to purebreds NMER and Gaint Flander rabbits; direct and maternal additive effects; direct and maternal heterosis effects and direct recombination effects between for growth traits.

\section{Materials and Methods}

\subsection{Animals and Experimental design}

This study was located at Sakha research farm belonging to Animal Production Research Institute (APRI), Agricultural Research Center, Egypt for 4 years, 2016-2020. Experimental procedures were conducted accordance with Animal Ethics Committee guideline of APRI, and the study plan was approved by the Institute's Research Committee in December 2015 (code no. 020203429).

A crossbreeding was carried out by mating bucks of Gaint Flander $(G)$ and does of Native of Mid-Egypt rabbit (NMER) to get $F 1\left(1 / 2 \mathrm{~N}^{1} / 2 \mathrm{G}\right)$, then does and bucks of this $\mathrm{F} 1$ were mated to get the $\mathrm{F} 2(1 / 2 \mathrm{~N} 1 / 2 \mathrm{G})$, followed by two generations of inter se-mating to get a new synthetic line is called Egy-Line with a genetic structure of $\left(\left(1 / 2 \mathrm{~N}^{1 / 2} \mathrm{G}\right)^{2}\right)^{2}$.

A total of 69 sires and 338 dams used for producing 1270rabbits were used for collection the data. The traits recorded were individual body weight (BW) at 4, 6, 8, 10 and 12 weeks of age. Also, relative growth rate (RGR) measured according to [10] as equal $=(\mathrm{W} 2-$ W1 $/(1 / 2(\mathrm{~W} 2-\mathrm{W} 1)) \times 100$, where W1 was body weight at the beginning of the period, and W2, body weight at the end of the period. Relative growth rates were at different age intervals by week (W); 5-6W, 6-8W, 8-10W, 10-12W, 12-14W, 14-16W, 16-18W, 18-20W and 5-20W.

\subsection{Animal Management}

Bucks and doses of rabbits were housed individually in metal cages $(40 \times 50 \times 60 \mathrm{~cm})$ which provided with nipple watering and metal feeders. The does introduced to buck's cage and the date of service was recorded and dose palpated at about 14th day after service. Before expected date of kindling by about 3 days, the cage of positive doses attached by nest boxes $(40 \times 40 \times 40 \mathrm{~cm})$ with some clean rice straw. Negative palpated does were reintroduced to buck's cage again after palpation. Kits were weaned at thirty days of age by transferring them to the fattening cages $(40 \times 50 \times 50 \mathrm{~cm})$ which were provided with metal feeders and nipple watering system. Kits were identified by metal numbers in ear. The rabbits were fed ad libitum with commercial pelleted diets had $17.5 \%$ crude protein, $14-16 \%$ crude fibers and $2300-2500 \mathrm{kcal} / \mathrm{kg}$ diet digestible energy. The cages were daily 
cleaned by removing the manure while maintaining a good ventilation and temperature as possible inside the house.

\subsection{Statistical analysis}

Variances and co-variances were obtained using REML method of VARCOMP procedure of (SAS, Cary, North Carolina, USA, and www.sas.com). Data were analyzed by applying the single-trait animal model of body weights and growth traits by applying STDFREML programs of [11].

Values of starting mixed model were received by applying REML method of VARCOMP procedure of in SAS 9.3 statistical analysis software (www.sas.com). Data were analyzed using a single-trait animal model of body weights and growth traits using STDFREML programs of [11], to obtain the heritability $\left(\mathrm{h}^{2}\right)$; common litter effects $\left(\mathrm{c}^{2}\right)$; random error effects $\left(\mathrm{e}^{2}\right)$. Analyses were done according to the general model: $\mathrm{y}=\mathrm{Xb}+\mathrm{Z1a}+$ $Z 2 p+$ e.(Model: 1). Where: $y=$ Vector of record of the trait, $X=$ Incidence matrix of fixed effects; $b=$ vector of fixed effects of genetic groups of rabbits (5 levels); Z1and Z2= incidence matrices corresponding to random effects of additive (a) and common litter effect (p), respectively.

Data were carried out by weighted least-squares means a method in the procedure GLM in SAS 9.3. To obtain least-squares and used to compare means by Duncan's multiple range test for the traits characteristics. $Y i=\mu+B i+$ ei. (Model:2). Where: $Y i=$ the parameters on the $i^{\text {th }}$ body weights and relative growth traits, $\mu=$ the overall mean, $B i=$ the fixed effect of the $i^{\text {th }}$ of genetic groups of rabbits ( $i=5$ levels) and ei $=$ the random deviation of all the other effects no specified the model. However, least-squares means were used as input data for the program package CBE, version 4.0 [12] that were used to estimate the crossbreeding parameters for every group of crossbreds and all analyzed traits. The estimation was carried out by weighted least squares means according to the Dickerson model [13].

\section{Results and Discussion}

\subsection{Means and coefficients of variation (CV\%) of traits}

Means estimates of body weights increase with age while relative growth rates (RGR) at different ages decrease with age (Table 1). This may be due to the rapid growth of rabbits at young ages, and within the range noted by [14]. With the previous results, improvement in growth rates may be achieved by applying phenotypic selection. Estimates of coefficient of variation $(\mathrm{CV} \%)$ for body weights decreased with age and this trend may be reflected with the bunnies' advance in age, and they become progressively less sensitive to non-genetic maternal effects [15]. CV\% in the relative growth rates estimates during all periods were not at the same pace and were ranged between 13.3 to 39.4 and this is in agreement with findings [14] while they higher than coefficient of variation of the growth traits in findings [16] that ranged between $21 \%$ to $28 \%$. 
Table 1. Means \pm S.E and coefficients of variation (CV\%) of body weights and relative growth rates (RGR)

\begin{tabular}{|c|c|c|c|}
\hline Traits & \multirow{2}{*}{ Means(g) } & \multirow{2}{*}{ $\pm S . E$} & \multirow{2}{*}{ CV\% } \\
\hline Body weights: & & & \\
\hline 5 weeks & 467.0 & 3.6 & 27.2 \\
\hline 6 weeks & 584.2 & 4.3 & 25.9 \\
\hline 8 weeks & 803.6 & 5.8 & 24.9 \\
\hline 10 weeks & 1088.3 & 7.7 & 22.8 \\
\hline 12 weeks & 1329.6 & 9.3 & 21.1 \\
\hline 14 weeks & 1558.7 & 11.0 & 19.6 \\
\hline 16 weeks & 1735.2 & 12.6 & 19.1 \\
\hline 18 weeks & 1923.0 & 13.9 & 18.5 \\
\hline 20 weeks & 2127.3 & 15.2 & 17.9 \\
\hline \multicolumn{4}{|c|}{ RGR at age intervals: } \\
\hline 5-6 week & 21.8 & 0.25 & 39.3 \\
\hline 6-8 week & 31.2 & 0.36 & 39.4 \\
\hline 8-10 week & 28.1 & 0.33 & 37.7 \\
\hline 10-12 week & 18.8 & 0.22 & 34.4 \\
\hline 12-14 week & 15.3 & 0.14 & 25.5 \\
\hline 14-16 week & 11.8 & 0.14 & 32.0 \\
\hline 16-18 week & 10.3 & 0.11 & 33.4 \\
\hline 18-20 week & 10.2 & 0.10 & 26.6 \\
\hline 5-20 week & 125.2 & 0.67 & 13.3 \\
\hline
\end{tabular}

\subsection{Heritabilities and common litter effects}

Heritabilities estimates for body weights and relative growth rate were generally moderate and ranged from 0.10 to 0.24 (Table 2). Values of the heritabilities in body weight are nearly to the estimates obtained by $[17,18]$. The estimates of heritabilities for RGR were low and moderate and ranged from 0.01 to 0.23 (Table 2). These heritabilities are higher than the heritabilities estimated by [16] with ranges $0.033-0.059$ in growth traits. The estimates of heritability can be indicators for the selection procedure to improve the body weight in different ages. However, the variations in heritability estimates could be attributed to changes in estimation methods, as well as the role of diverse environmental factors. The moderate heritabilities found here for body weights could indicate that body weight improvement could be accomplished through selection [14].

Common little effect $\left(\mathrm{c}^{2}\right)$ of body weight and relative growth rate were large as weaning then declined gradually as the rabbit grew older at 20 weeks of age (Table2). There is evidence that the maternal and common environmental effects are a rapid reduction with over time, so the estimates are higher for growth at weaning than at the end of the fattening period in rabbits. These result in agreement with[19, 20, 17, 14]. 
Table 2. Heritabilities $\left(\mathrm{h}^{2}\right)$, common little $\boldsymbol{e}$ ffect $\left(\mathrm{c}^{2}\right)$ and error $\left(\mathrm{e}^{2}\right)$, relative to phenotypic variance for body weights and relative growth rate (RGR) traits with their standard errors $( \pm S E)$

\begin{tabular}{|c|c|c|c|}
\hline Traits & & & \\
\hline \multicolumn{4}{|l|}{ Body weights at: } \\
\hline 5 weeks & $0.19 \pm 0.08$ & $0.61 \pm 0.04$ & $0.21 \pm 0.05$ \\
\hline 6 weeks & $0.21 \pm 0.08$ & $0.58 \pm 0.04$ & $0.22 \pm 0.05$ \\
\hline 8 weeks & $0.12 \pm 0.08$ & $0.49 \pm 0.05$ & $0.39 \pm 0.05$ \\
\hline 10 weeks & $0.16 \pm 0.09$ & $0.39 \pm 0.05$ & $0.45 \pm 0.07$ \\
\hline 12 weeks & $0.10 \pm 0.08$ & $0.36 \pm 0.05$ & $0.54 \pm 0.06$ \\
\hline 14 weeks & $0.14 \pm 0.10$ & $0.30 \pm 0.06$ & $0.56 \pm 0.08$ \\
\hline 16 weeks & $0.24 \pm 0.01$ & $0.18 \pm 0.05$ & $0.58 \pm 0.04$ \\
\hline 18 weeks & $0.18 \pm 0.01$ & $0.25 \pm 0.03$ & $0.58 \pm 0.04$ \\
\hline 20 weeks & $0.17 \pm 0.01$ & $0.27 \pm 0.05$ & $0.55 \pm 0.04$ \\
\hline \multicolumn{4}{|c|}{ RGR at age intervals: } \\
\hline 5-6 week & $0.23 \pm 0.11$ & $0.40 \pm 0.06$ & $0.37 \pm 0.07$ \\
\hline 6-8 week & $0.20 \pm 0.09$ & $0.28 \pm 0.04$ & $0.52 \pm 0.06$ \\
\hline 8-10 week & $0.18 \pm 0.07$ & $0.25 \pm 0.04$ & $0.57 \pm 0.06$ \\
\hline 10-12 week & $0.06 \pm 0.05$ & $0.25 \pm 0.05$ & $0.68 \pm 0.06$ \\
\hline 12-14 week & $0.01 \pm 0.07$ & $0.16 \pm 0.05$ & $0.83 \pm 0.06$ \\
\hline 14-16 week & $0.01 \pm 0.07$ & $0.15 \pm 0.05$ & $0.84 \pm 0.05$ \\
\hline 16-18 week & $0.09 \pm 0.11$ & $0.14 \pm 0.06$ & $0.77 \pm 0.08$ \\
\hline 18-20 week & $0.02 \pm 0.07$ & $0.16 \pm 0.06$ & $0.82 \pm 0.06$ \\
\hline 5-20 week & $0.13 \pm 0.14$ & $0.59 \pm 0.08$ & $0.28 \pm 0.08$ \\
\hline
\end{tabular}

RGR $=$ Relative growth rate (\%)

\subsection{Genetic groups and comparisons}

The least-square means and standard errors for body weight and relative growth rate traits in purebreds and crossbreds are given in Table 3. Highly significant differences were observed among different genotypes for almost all traits. In general, the crossbred rabbits were somewhat higher than the purebreds and they are within the range observed by [21, $22,23,24,25]$. However, the new rabbit line resulting from the crossing program called Egy-line proved to be superior in all different body weights and was the highest compared to the parents. The crossbreed showed superiority in growth rate comparing to the parents except for RGR16-18 and RGR18-20. From these results, it is recommended to increase the new line (Egy-line) and use it as a line for producing meat. 
Table 3. Least-square means body weights (g), relative growth rate (RGR) and their standard errors (S.E) in different genetic groups.

\begin{tabular}{|c|c|c|c|c|c|}
\hline Genetic groups & $\mathbf{N X N}$ & GXG & $1 / 2 N^{1 / 2} \mathbf{G}$ & $\begin{array}{c}1 / 2 N^{1} / 2 G X \\
1 / 2 N^{1} / 2 G\end{array}$ & Egy-line \\
\hline Traits & \multirow{2}{*}{ Mean $\pm S E$} & \multirow{2}{*}{ Mean \pm SE } & \multirow{2}{*}{ Mean \pm SE } & \multirow{2}{*}{ Mean \pm SE } & \multirow{2}{*}{ Mean \pm SE } \\
\hline Body weights: & & & & & \\
\hline 5 weeks & $444.0 \pm 6.4^{b}$ & $456.7 \pm 8.9 b$ & $499.0 \pm 9.8 \mathrm{a}^{\mathrm{a}}$ & $441.4 \pm 9.4 \mathrm{~b}$ & $489.0 \pm 13.5^{\mathrm{ab}}$ \\
\hline 6 weeks & $542.9 \pm 7.2 \mathrm{c}$ & $576.2 \pm 10.2 \mathrm{cb}$ & $616.9 \pm 11.2 b$ & $575.2 \pm 11.3 \mathrm{~b}$ & $655.1 \pm 15.2$ a \\
\hline 8 weeks & $713.7 \pm 9.7 \mathrm{~d}$ & $804.8 \pm 14.5^{c}$ & $872.5 \pm 16.3^{b}$ & $850.2 \pm 15.2 \mathrm{cb}$ & $949.6 \pm 20.9$ a \\
\hline 10 weeks & $959.8 \quad 14.8^{\mathrm{d}}$ & $1086.0 \pm 18.4^{c}$ & $1152.4 \pm 21.2 \mathrm{cb}$ & $1175.7 \pm 19.0^{b}$ & $1262.8 \pm 26.2^{a}$ \\
\hline 12 weeks & $1169.4 \pm 18.7^{\mathrm{d}}$ & $1327.7 \pm 21.3^{c}$ & $1367.3 \pm 25.7$ c & $1421.1 \pm 21.3^{b}$ & $1529.9 \pm 29.6^{a}$ \\
\hline 14 weeks & $1388.2 \pm 22.7^{\mathrm{d}}$ & $1554.0 \pm 31.5 \mathrm{cb}$ & $1539.2 \pm 29.5^{c}$ & $1632.9 \pm 23.9 b$ & $1783.4 \pm 33.8^{\mathrm{a}}$ \\
\hline 16 weeks & $1541.6 \pm 30.3^{d}$ & $1705.5 \pm 37.0$ b & $1644.5 \pm 26.7$ c & $1802.8 \pm 26.6^{b}$ & $1985.4 \pm 37.8^{a}$ \\
\hline 18 weeks & $1744.4 \pm 35.3 \mathrm{c}$ & $1893.8 \pm 40.2$ b & $1801.7 \pm 37.2$ b & $1980.0 \pm 28.7$ c & $2170.7 \pm 28.7^{a}$ \\
\hline 20 weeks & $1982.6 \pm 41.4^{\mathrm{c}}$ & $2101.5 \pm 41.1^{b}$ & $1975.7 \pm 40.1 \mathrm{c}$ & $2170.1 \pm 44.0^{\mathrm{b}}$ & $2379.1 \pm 44.0^{a}$ \\
\hline \multicolumn{6}{|l|}{ RGR in intervals: } \\
\hline 5-6 week & $20.2 \pm 0.40^{c}$ & $23.5 \pm 0.56^{b}$ & $21.1 \pm 0.62 \mathrm{c}$ & $29.9 \pm 0.62$ b & $28.1 \pm 0.83^{a}$ \\
\hline 6-8 week & $27.9 \pm 0.61^{c}$ & $31.8 \pm 0.91^{b}$ & $30.4 \pm 1.0^{\mathrm{b}}$ & $39.2 \pm 0.96^{a}$ & $36.3 \pm 1.3^{a}$ \\
\hline 8-10 week & $26.9 \pm 0.64^{\mathrm{d}}$ & $29.6 \pm 0.80 \mathrm{ab}$ & $27.2 \pm 0.92 \mathrm{~cd}$ & $31.8 \pm 0.83^{a}$ & $29.9 \pm 1.1^{b c}$ \\
\hline 10-12 week & $18.5 \pm 0.48^{a b}$ & $19.3 \pm 0.55^{\mathrm{ab}}$ & $17.1 \pm 0.66^{b}$ & $19.5 \pm 0 .{ }^{\mathrm{a}} 55^{\mathrm{a}}$ & $19.4 \pm 0.77^{a}$ \\
\hline 12-14 week & $15.0 \pm 0.47 \mathrm{a}$ & $14.7 \pm 0.44 \mathrm{cb}$ & $14.0 \pm 0.41^{c}$ & $15.0 \pm 0.33 \mathrm{cb}$ & $16.5 \pm 0.32^{b}$ \\
\hline 14-16 week & $11.8 \pm 0.47 a$ & $11.5 \pm 0.46 \mathrm{cb}$ & $10.5 \pm 041^{c}$ & $11.8 \pm 0.33 \mathrm{cb}$ & $13.02 \pm 0.38^{b}$ \\
\hline 16-18 week & $11.6 \pm 0.36^{a}$ & $10.5 \pm 0.41^{b}$ & $9.2 \pm 0.38$ b & $10.0 \pm 0.29 b$ & $9.9 \pm 0.41^{b}$ \\
\hline 18-20 week & $11.1 \pm 0.32^{a}$ & $9.7 \pm 0.31$ b & $9.8 \pm 0.34$ b & $9.9 \pm 0.23 b$ & $10.9 \pm 0.33^{a}$ \\
\hline 5-20 week & $120.2 \pm 1.7^{b}$ & $127.7 \pm 1.7 \mathrm{~b}$ & $114.8 \pm 1.6^{c}$ & $132.1 \pm 1.3^{a}$ & $130.8 \pm 1.8^{a}$ \\
\hline
\end{tabular}

RGR = Relative growth rate $(\%)$

\subsection{Comparing synthetic Egy-line with purebreds}

Deviations of Egy-line from the parent purebreds (NMER and Gaint Flander) were positive and highly significant $\mathrm{P}<0.01$ ) for all body weights at different ages (Table 4). The new synthetic line was superior for the NMER (N) in body weights and the largest superiorities were by 45.0, 112.2, 235.9, 303.0, 360.5, 395.2, 443.8, 426.3 and 396.5 at 5, 6, 8, $10,12,14,16,18$ and 20 weeks of age. Also, the same trends were observed for growth rate during different intervals except for growth rate during 10 to 12 weeks and 18 to 20 weeks (Table 4).

From these results, the Egy-line rabbits performed well for body weights and growth rates. Egy-line is characterized by rapid growth in obtaining hybrid rabbits and it involves in a crossbreeding program with other local rabbits under Egyptian conditions. Many researchers have worked on the crossing between breeds, and their results are almost consistent with the results of this study. [17] established the synthetic line between the V line and Baladi Red (BR) breed rabbits and named APRI-line that appears intermediate between the founders in growth traits when raised in environmental conditions of experiments in the Delta-Egypt. In these conditions, the APRI was a better alternative for the BR breed but worse than $\mathrm{V}$ line and they suggested more studies are needed to know the performance of APRI-line under different Egyptian regions' conditions. [24] reported that synthetic rabbit line by crossing V-line and Saudi Gabali breed rabbits as a project to be convenient in hot climate areas of Saudia. So, these synthetic lines could be used in commercial farms. 
Table 4. The improvement in synthetic line, (Egy-line) comparing to purebreds for body weights and relative growth traits.

\begin{tabular}{|c|c|c|}
\hline & \multicolumn{2}{|c|}{ Improvement in Egy-line relative to } \\
\hline Traits & NMER (N) & Ganit Flander (G) \\
\hline Body weights at age: & Contrast \pm SE & Contrast \pm SE \\
\hline 5 weeks & $45.0 \pm 14.9^{* *}$ & $32.0 \pm 16.2^{* *}$ \\
\hline 6 weeks & $112.2 \pm 16.8^{* *}$ & $78 . .9 \pm 18.3^{* *}$ \\
\hline 8 weeks & $235.9 \pm 23.0^{* *}$ & $144.8 \pm 25.4^{* *}$ \\
\hline 10 weeks & $303.0 \pm 30.1^{* *}$ & $176.8 \pm 32.0^{* *}$ \\
\hline 12 weeks & $360.5 \pm 34.9^{* *}$ & $202.2 \pm 36.5^{* *}$ \\
\hline 14 weeks & $395.2 \pm 40.7^{* *}$ & $229.4 \pm 46.2^{* *}$ \\
\hline 16 weeks & $443.8 \pm 48.8^{* *}$ & $279.9 \pm 52.9^{* *}$ \\
\hline 18 weeks & $426.3 \pm 45.5^{* *}$ & $276.9 \pm 49.4^{* *}$ \\
\hline 20 weeks & $396.5 \pm 60.7^{* *}$ & $277.6 \pm 60.2^{* *}$ \\
\hline \multicolumn{3}{|l|}{ RGR at age intervals: } \\
\hline 5-6 week & $7.9 \pm 0.92^{* *}$ & $4.6 \pm 1.0^{* *}$ \\
\hline 6-8 weeks & $8.4 \pm 1.4^{* *}$ & $4.5 \pm 1.6^{* *}$ \\
\hline 8-10 week & $3.0 \pm 1.6^{*}$ & $0.30 \pm 1.9^{\mathrm{ns}}$ \\
\hline 10-12 week & $0.90 \pm 0.91^{\mathrm{ns}}$ & $0.10 \pm 0.95^{\mathrm{ns}}$ \\
\hline 12-14 week & $1.5 \pm 0.57^{* *}$ & $1.8 \pm 0.54^{* *}$ \\
\hline 14-16 week & $1.2 \pm 0.60^{*}$ & $1.5 \pm 0.59^{* *}$ \\
\hline 16-18 week & $-1.7 \pm 0.55^{* *}$ & $-0.60 \pm 0.58 \mathrm{~ns}$ \\
\hline 18-20 week & $-0.20 \pm 0.46^{\mathrm{ns}}$ & $1.2 \pm 0.45^{* *}$ \\
\hline 5-20 week & $10.6 \pm 2.5^{* *}$ & $3.1 \pm 2.4^{\mathrm{ns}}$ \\
\hline
\end{tabular}

$\mathrm{NS}=$ not significant at $\mathrm{P}>0.05 ;^{*}=\mathrm{P}<0.05 ;{ }^{* *}=\mathrm{P}<0.01 ; \mathrm{RGR}=$ relative growth traits

\subsection{Direct $\left(G^{I}\right)$ and maternal additive $\left(G^{M}\right)$ effects}

Estimates of direct additive effect were positive and highly significant $\mathrm{P}<0.01$ ) for all body weights at different ages, favoring Ganit Flander and heavier by 45, 112.2, 235.9, $303,360.5,395.2,443.8,426.3$, and $396.5 \mathrm{~g}$ at 5, 6, 8, 10, 12, 14, 16, 18 and 20 weeks of age comparing with NMER rabbits (Table 5). The obtained results for most relative growth traits during different intervals except between 10 to 12 and 18 to 20 weeks, were nonsignificant and between 16 to 18 were negative and significant.

As well Ganit Flander was highly significant and heavier in maternal additive effects by $32,78.9,144.8,176.8,202.2,229.4,279.9,276.9$ and $277.6 \mathrm{~g}$ at $5,6,8,10,12,14,16,18$, and 20 weeks of age comparing with NMER rabbits. Also, Ganit Flander was highly significant and heavier in maternal additive effects for most growth rates during different intervals. These results are in agreement with many researchers, [26]noted that direct and maternal additive effects on post-weaning body weight traits were significant $(\mathrm{P}<0.01)$ and favouring V-line rabbits comparing Baladi Black ones. [27]reported that Gabali breed was superior in direct and maternal additive effects over the $\mathrm{V}$ line for body weights at 8 and 12 weeks and daily gains in 4-8 and 8-12 week. They reported that percentages of these estimates relative to the averages of Gabali and $\mathrm{V}$ line were 5.2, 6.6, 5.3, 11.1 and $21.3 \%$ for W4, W8, W12, DG4-8, and DG8-12, respectively.

Likewise [7] found that the superiority of the Gabali breed in growth was over the $\mathrm{V}$ line while the superiority in prolificacy exhibited in V line. So, crossing between Gabali and $\mathrm{V}$ line was carried out to appear the beneficial complementarity in the global performance and producing synthesized line named Moshtohor. [17] reported that the differences in direct additive effects among the $\mathrm{V}$-line and Baladi Red rabbits were in favor of $\mathrm{V}$ line rabbits for reaching $15.0 \%(76 \mathrm{~g})$ at 4 weeks and $13.3 \%(195 \mathrm{~g})$ at 12 weeks and 
estimates of daily gains reaching $35.7 \%(7.19 \mathrm{~g} / \mathrm{d})$ in the interval of $10-12$ weeks. [24] reported that most estimates of direct genetic effects for body weights and daily gains were in favour of $\mathrm{V}$-line rabbits, and differences in direct and maternal genetic effects among the two lines were moderate and reaching $13.1 \%$ for daily gain in the interval of $10-12$ weeks. For direct genetic effects, V line rabbits were significantly heavier by 28.6, 31.1, 62.6, 114.8, and $189.4 \mathrm{~g}$ than the Saudi Gabali at 4, 6, 8, and 10 and 12 weeks of age, respectively[24].

Also, $\mathrm{V}$ line rabbits were significantly heavier in maternal genetic effects by $43.8,46.4$, $70.9,78.5$ and $81.6 \mathrm{~g}$ than Saudi Gabali at the same ages. Furthermore, both direct and maternal genetic effects were significantly heavier in daily gain weight by values ranging from 0.9 to $3.37 \mathrm{~g}$ at all age intervals studied $[24,25]$ reported that the direct genetic effect of New Zealand White (NZW) was positive for all growth traits studied while the body weight (BW) at $8^{\text {th }}$ week, growth rate at 4-6 and at 6-8 weeks of age were negative, their values $-37 \mathrm{~g},-64 \mathrm{~g},-1.62 \%$ and $-4.71 \%$, respectively. The estimates for Californian (Cal) breed were negative for all growth traits with the exception of BW at $4^{\text {th }}$ week and growth rate at 8-10, and at 10-12 weeks of age. Rex (RR) rabbits showed nearly equal distribution of negative and positives estimates of direct genetic effect among traits under investigation. This study reported that additive sire effect is higher in NZW rabbit for weaning and postweaning growth traits and it is better to be used as sire breed than Cal and RR.

Table 5. Direct $\left(\mathrm{G}^{\mathrm{I}}\right)$ and maternal $\left(\mathrm{G}^{\mathrm{M}}\right)$ additive effects and their standard errors $( \pm \mathrm{SE})$ for body weights and relative growth rate (RGR).

\begin{tabular}{|c|c|c|c|c|}
\hline \multirow{2}{*}{\begin{tabular}{|l|} 
Traits \\
Body weights:
\end{tabular}} & \multicolumn{2}{|c|}{ Direct additive (GI) } & \multicolumn{2}{|c|}{ Maternal additive(GM) } \\
\hline & Units \pm SE & G1\% & Units \pm SE & $\mathrm{G}^{\mathrm{M} \%}$ \\
\hline 5 weeks & $12.7 \pm 6.4^{* *}$ & 2.8 & $31.1 \pm 9.1^{* *}$ & 6.9 \\
\hline 6 weeks & $33.3 \pm 12.5^{* *}$ & 6.0 & $52.1 \pm 10.4^{* *}$ & 9.3 \\
\hline 8 weeks & $91.1 \pm 17.4^{* *}$ & 12.0 & $122.6 \pm 14.5^{* *}$ & 16.1 \\
\hline 10 weeks & $126.2 \pm 23.6^{* *}$ & 12.3 & $153.5 \pm 20.3^{* *}$ & 15.0 \\
\hline 12 weeks & $158.3 \pm 28.1^{* *}$ & 12.7 & $171.2 \pm 24.6^{* *}$ & 13.7 \\
\hline 14 weeks & $165.8 \pm 38.8^{* *}$ & 11.3 & $155.7 \pm 31.3^{* *}$ & 10.6 \\
\hline 16 weeks & $163.9 \pm 47.8^{* *}$ & 10.1 & $105.1 \pm 37.1 * *$ & 6.5 \\
\hline 18 weeks & $149.4 \pm 53.5^{* *}$ & 9.0 & $69.0 \pm 44.5^{* *}$ & 3.8 \\
\hline 20 weeks & $118.9 \pm 58.6^{* *}$ & 5.8 & $28.3 \pm 50.5^{* *}$ & 1.4 \\
\hline \multicolumn{5}{|c|}{ RGR at age intervals } \\
\hline 5-6 week & $3.3 \pm 0.69^{* *}$ & 15.1 & $2.2 \pm 0.58^{* *}$ & 10.1 \\
\hline 6-8 weeks & $3.9 \pm 1.1^{* *}$ & 13.1 & $3.3 \pm 0.91^{* *}$ & 11.1 \\
\hline 8-10 week & $2.7 \pm 1.0^{* *}$ & 9.6 & $1.7 \pm 0.88^{\mathrm{ns}}$ & 6.0 \\
\hline 10-12 week & $0.80 \pm 0.73^{\mathrm{ns}}$ & 4.2 & $-0.11 \pm 0.64$ ns & -0.58 \\
\hline 12-14 week & $-0.30 \pm 0.64^{\mathrm{ns}}$ & -2.0 & $-1.0 \pm 0.55^{\mathrm{ns}}$ & -6.7 \\
\hline 14-16 week & $-0.29 \pm 0.65 \mathrm{~ns}$ & -2.5 & $1.1 \pm 0.56^{*}$ & 9.4 \\
\hline 16-18 week & $-1.1 \pm 0.54^{*}$ & -10.0 & $-1.8 \pm 0.45^{* *}$ & -16.3 \\
\hline 18-20 week & $-1.4 \pm 0.45^{* *}$ & -13.5 & $-1.4 \pm 0.38^{* *}$ & -13.5 \\
\hline 5-20 week & $7.5 \pm 2.3^{* *}$ & 6.1 & $0.60 \pm 2.0^{\mathrm{ns}}$ & 0.48 \\
\hline
\end{tabular}

\subsection{Direct (HI) and maternal heterosis (HM) effects}

Estimates of direct heterosis effect for most the body weights were positive and highly significant $(\mathrm{P}<0.01)$, and percentages of direct heterosis increased generally with the advance of age (Table 6). Direct heterosis effects for mostly RGR during different intervals were negative and not significant. 
Generally, estimates of maternal heterosis for body weight were positive and highly significant $(\mathrm{P}<0.01)$, and percentages of maternal heterosis ranged from 3.9 to $16.0 \%$. Maternal heterosis for growth rates from 5 to 6,8 to 10 , and 10 to 12 weeks was positive and highly significant while the restated of the periods they were between negative, positive and significant. These results are within the scope of the results obtained by many researchers, such as [26], who reported that direct and maternal heterosis effects on postweaning body weight traits were significant. [27]noted that estimates of direct heterosis effects were positive and significant for several of the studied traits and percentages were $6.9,3.6,5.4,9.7$, and $6.1 \%$ for BW4, BW8, BW12, DG4-8 and DG8-12, respectively. Percentages of maternal heterosis for the same traits were the same trends for BW4 and DG4-8. [17] observed that the estimates of direct heterosis were positive and significant, ranging from 4.9 to $16.7 \%$ for body weights and 14.4 to $29.5 \%$ for daily gains, while the estimates for maternal heterosis were mainly negative, ranging from -4.5 to $-5.2 \%$ for body weights and from 20.6 to $-36.9 \%$ for daily gains. [24] reported that direct heterosis for body weights and daily gains were significantly positive and ranged from 4.5 to $9.6 \%$. Estimates of maternal heterosis were mainly significantly positive and ranged from 1.5 to $6.0 \%$. Estimates of direct (maternal) heterosis in grams were 29.1 (34.3), 61.4 (17.5), 69.7 (36.1), 98.6 (52.9), and 124.4 (74.8) for body weights at 4, 6, 8, 10, and 12 weeks of age, respectively. [25] noted that strong individual heterosis was estimated for NZW X Cal crossbreds for all body weights, especially at $6^{\text {th }}$ week of age $(20.24 \%)$ and most of BWG, especially at $4-6$ weeks of age (25.89\%). However, negative estimates were recorded for most of RGR. In contrast, $\mathrm{NZW} \times \mathrm{Cal}$ and RR crossbreeding, they showed negative estimates for all studied traits at most ages and age intervals [25]. Through the results of this study and other research, it is possible to improve growth traits by crossing.

\subsection{Direct recombination effects (RI)}

Direct recombination effects (RI) for most bodyweight were positive and highly significantly exclude $w$ ight at 5 and 6 weeks (Table 6). Also, RI for growth rates during different intervals exclude during from 16 to 18 and from 18 to 20 were not significant (Table 6). These results are consistent with [28], who studied the RI for body weight at 4, 8, 12, and 14 weeks and daily gain during intervals $4-14$. on the contrary, the results are in finding of [29] who reported that RI loss was negative and highly significant for body weights (from -14.72 g to $493.51 \mathrm{~g}$ ). [24] observed that RI was not significant. They suggested that these estimates gave the impression to indicate that the crossbred dams, including the $\mathrm{V}$-line genes, could be effective in improving growth performance after weaning by crossing the $\mathrm{V}$-line with the native rabbits. 
Table 6. Direct $\left(\mathrm{H}^{\mathrm{I}}\right)$ and maternal $\left(\mathrm{H}^{\mathrm{M}}\right)$ heterosis and direct recombination effect and their standard errors $( \pm S E)$ for growth traits.

\begin{tabular}{|c|c|c|c|c|c|}
\hline \multirow{2}{*}{$\begin{array}{c}\text { Traits } \\
\text { Body weights: }\end{array}$} & \multicolumn{2}{|c|}{$\begin{array}{c}\text { Direct heterosis } \\
\left(\mathrm{H}^{\mathrm{I}}\right)\end{array}$} & \multicolumn{2}{|c|}{$\begin{array}{c}\text { Maternal heterosis } \\
\left(\mathrm{H}^{\mathrm{M}}\right)\end{array}$} & \multirow{2}{*}{$\begin{array}{c}\text { Recombination } \\
\left(\mathbf{R}^{\mathrm{I}}\right)\end{array}$} \\
\hline & Units \pm SE & $\mathrm{H}^{\mathrm{I} \%}$ & Units \pm SE & H м\% & \\
\hline 5 weeks & $-12.4 \pm 10.2^{\mathrm{ns}}$ & -2.8 & $48.7 \pm 10.9 \mathrm{~ns}$ & 10.8 & $-35.5 \pm 19.1 \mathrm{~ns}$ \\
\hline 6 weeks & $57.4 \pm 12.8^{* *}$ & 10.3 & $21.9 \pm 12.1^{\mathrm{ns}}$ & 3.9 & $30.8 \pm 22.2^{\mathrm{ns}}$ \\
\hline 8 weeks & $113.2 \pm 18.5^{* *}$ & 14.9 & $100.1 \pm 16.4^{* *}$ & 13.2 & $137.4 \pm 30.7^{* *}$ \\
\hline 10 weeks & $129.5 \pm 24.3^{* *}$ & 12.7 & $163.7 \pm 21.1^{* *}$ & 16.0 & $236.1 \pm 39.2^{* *}$ \\
\hline 12 weeks & $118.8 \pm 29.3^{* *}$ & 9.5 & $192.5 \pm 24.2^{* *}$ & 15.4 & $300.6 \pm 45.0^{* *}$ \\
\hline 14 weeks & $68.1 \pm 35.3 \mathrm{~ns}$ & 4.6 & $194.0 \pm 28.2^{* *}$ & 13.2 & $355.8 \pm 52.6^{* *}$ \\
\hline 16 weeks & $20.9 \pm 36.8 \mathrm{~ns}$ & 1.3 & $229.4 \pm 32.2^{* *}$ & 14.1 & $458.5 \pm 56.2^{* *}$ \\
\hline 18 weeks & $-17.4 \pm 45.8^{\mathrm{ns}}$ & -0.96 & $225.7 \pm 36.0^{* *}$ & 12.4 & $529.9 \pm 61.2^{* *}$ \\
\hline 20 weeks & $-66.9 \pm 49.7 \mathrm{~ns}$ & -3.3 & $252.9 \pm 49.2^{* *}$ & 12.4 & $532.1 \pm 61.2^{* *}$ \\
\hline \multicolumn{6}{|c|}{ RGR at age intervals: } \\
\hline 5-6 week & $-0.75 \pm 0.70 \mathrm{~ns}$ & -3.4 & $6.3 \pm 0.66^{* *}$ & 28.8 & $11.7 \pm 1.2^{* *}$ \\
\hline 6-8 weeks & $0.54 \pm 1.1^{\mathrm{ns}}$ & 1.8 & $10.0 \pm 1.0^{* *}$ & 33.5 & $16.1 \pm 1.8^{* *}$ \\
\hline 8-10 week & $-1.0 \pm 1.1^{\mathrm{ns}}$ & -3.5 & $4.1 \pm 0.92^{* *}$ & 14.5 & $6.8 \pm 1.7^{* *}$ \\
\hline 10-12 week & $-1.8 \pm 0.75^{* *}$ & -9.5 & $\pm 1.1 \pm .62 \mathrm{~ns}$ & 5.8 & $2.9 \pm 1.2^{* *}$ \\
\hline 12-14 week & $-0.81 \pm 0.52 \mathrm{~ns}$ & -5.5 & $0.51 \pm 0.43^{\mathrm{ns}}$ & 3.4 & $2.6 \pm 0.69^{* *}$ \\
\hline 14-16 week & $-1.2 \pm 0.52^{*}$ & -10.3 & $0.52 \pm 0.43^{\mathrm{ns}}$ & 4.5 & $2.5 \pm 0.72^{* *}$ \\
\hline 16-18 week & $1.9 \pm 0.47^{* *}$ & 17.2 & $-0.74 \pm 0.37^{*}$ & -6.7 & $-0.34 \pm 0.67 \mathrm{~ns}$ \\
\hline 18-20 week & $-0.59 \pm 0.37 \mathrm{~ns}$ & -5.7 & $-0.48 \pm 0.30^{\mathrm{ns}}$ & -4.6 & $0.25 \pm 0.53^{\mathrm{ns}}$ \\
\hline 5-20 week & $-9.2 \pm 2.0^{* *}$ & -7.4 & $11.7 \pm 1.6^{* *}$ & 9.5 & $24.6 \pm 2.9^{* *}$ \\
\hline
\end{tabular}

$\mathrm{NS}=$ not significant at $\mathrm{P}>0.05 ;^{*}=\mathrm{P}<0.05 ;{ }^{* *}=\mathrm{P}<0.01 ; \mathrm{RGR}=$ relative growth rate

\section{Conclusions}

Growth traits were affected by direct genetic effects and the maternal effects were less important. By heterosis, the new line (Egy-line)was synthesized, that has proven its superiority and performance well in all different body weights and most growth rates compared to the parents. Success combining the NMER as native genetic resource and the high productive breeds or line for forming a synthetic line could encourage more uses for NMER in crossbreeding schemes to synthetic line could perform well in Egypt. 1. Subsection.

Author Contributions: El-Sayed Abdel-Kafy contributed to project administration, Conceptual-ization, and editing; Amira S. El-Deighadi contributed to formal analysis and writing-review; Hoda Shabaan contributed to data curation and methodology; Wael H., Ali contributed in investigation and data curation; Zain El-Abdeen A. Sabra contributed in software and validation and A. Farid contributed in methodology and project administration.

Funding: This research was conducted within the framework of the project "Crossing NMER with Giant Flander and V line rabbits", which was funded by Animal Production Research Institute (APRI) in Egypt under code no. 020203429.

Acknowledgments: The authors greatly appreciate the help of staffs in the Rabbit farm, Sakha - Kafr El-Sheikh governorate, which belongs to APRI for their support in this research.

Conflicts of Interest: The authors declare no conflict of interest. The funders had no role in the design of the study; in the collection, analyses, or interpretation of data; in the writing of the manuscript; or in the decision to publish the results. 


\section{References}

[1] Badawy AG (1975) Rabbit Raising. Central Administration for Agricultural Culture, Ministry of Agriculture, Egypt (2nd Edition, In Arabic), pp. 75.

[2] Khalil MH (2002) TheBaladi Rabbits (Egypt). In: Khalil MH, Baselga M (Eds.) Rabbit genetic resources in Mediterranean countries. Options Méditerranénnes, Series B, Ciheam, Zaragoza, Spain, pp. 38-50.

[3] Imam A R Ahmed Mostafa, Dorina M, Mohamed S, Ayman A, Monica M. Rabbits Meat Production in Egypt and its Impact on Food Security, Small Holders Income and Economy. Agri Res\& Tech: Open Access J. 2020; 23(5): 556251. DOI: 10.19080/ARTOAJ.2020.22.556251.

[4] Brun J.M., Theau-Clément M., Bolet G., 2002. Evidence for heterosis and maternal effects on rabbit semen characteristics. Anim. Res., 51, 433-442.

[5] Abou Khadiga G.S.M., 2004. Performance of the Spanish synthetic line (V) and the local Baladi Black rabbits and their crosses under Egyptian conditions. M. Sc. Thesis, Faculty of Agriculture, Kafr El-Sheikh, Tanta University, Egypt.

[6] Khalil M.H., Hermes I.H., Mehaia M.A., Al-Homidan A.H., Al-Sobayil K.A., Al-Karaawy, A.A. 2005. Production of purebred and crossbred parents of rabbits to be distributed to breeders in Al-Qassim region. Kingdom of Saudi Arabia. King Abdulaziz city for Science and Technology General Directorate of Research Grants Programs. Al-Qassim University, Final Technical Report. ARP, 18-62.

[7] Iraqi M.M., Baselga M., Kalil M.H., Afifi E.A., García M.L., 2009. Line Moshtohor (Egypt). In Khalil M.H., Baselga, M. (Eds). Rabbit Genetic Resources in Mediterranean Countries. Options Mediterranean's, SeriesB, N 38o, Spain, http://www.iamz.ciheam.org/medrabbit/docs/moshtohor.pdf

[8] Galal ESE, Khalil MH (1994) Development of rabbit industry in Egypt. CIHEAM - Options Mediterraneennes, pp. $43-53$.

[9] Abel-Kafy EM, Shabaan HMA, Azoz AAA, El-Sayed AFM, Abdel-Latif AM (2011) Descriptions of native rabbit breeds in Middel-Egypt. Proceedings of the 4th Egyptian Conference of Rabbit Science, Giza, Egypt, pp: 1-14.

[10] Broody S (1945). Bioenergetics and growth. Reinhold Pub Crop NY, USA.

[11] Boldmann, K. G.; Kriese, L. A.; Van Tassell, C. P.; Kachman, S. D. (1995). A manual for use of MTDFREML. A set programs to obtain estimates of variances and covariance [DRAFT]. U.S. Department of Agriculture, Agricultural Research Service, USA.

[12] Wolf J., 1996. User's manual for the software package (C B E). Version 4.0. A universal program for estimating crossbreeding effects. Research Institute of Animal Production, Department of Genetics and Biometrics, PrahaUhÕ í nçves, Czech Republic

[13] Dickerson G.E. 1969. Experimental approaches in utilizing breed resources.Anim. Breed. Abstr., 37, 191-202.

[14] El-Deihadi S. Amira and M. K. Ibrahim, 2017. Genetic aspects of post-weaning for growth traits in New Zealand White rabbits. Egyptian Journal of Rabbit Science, 27 (2): 507-521.

[15] Khalil. H.H.; Afifi, E.A., and Owen, J.B., 1987. A genetic analysis of body weight traits in young Bauscat and Giza White rabbits. Anim. Prod., 45; 135-144.

[16] Ezzeroug R., R. Belabbas, M. José Argente, A. Berbar, S.Diss, Z. Boudjella, D. Talaziza, N. Boudahdir, and M. D. García. 2020. Genetic correlations for reproductive and growth traits in rabbits. Home Canadian Journal of Animal Science Volume 100, No: 2,

[17] Youssef, Y.K.Baselga, M., Khalil, M.H. Omara, M.E.,García, M.L., 2009. Crossbreeding effects for post-weaning growth traits in a project of Spanish V-line with Baladi Red rabbits in Egypt. Livestock Science, Elsevier 122: 302-30.Author 1, A.B.; Author 2, C.D. Title of the article. Abbreviated Journal NameYear, Volume, page range.

[18] Behiry, F. Fatamh, 2014. Genetic study for somebody measurements and its relationship with some productive traits in rabbits. Ph. D. Thesis, Fac. Agric., Tanta Univ., Egypt.

[19] García M.L. and Baselga M. 2002. Estimation of genetic response to selection in litter size of rabbits using a cryopreserved control population. Livest. Prod. Sci. 74: 45-53.

[20] Youssef, Y.K., Baselga, M., Khalil, M.H., Gad-Alla, S., García, M.L., 2008. Evaluation of litter traits in a crossing project of Spanish V-line and Baladi Red rabbits in Egypt. Livestock Research for Rural Development 20(9), Article 13.

[21] Maj D, Bieniek J, Łapa P, Ina S., (2009). The effect of crossing New Zealand White with Californian rabbits on growth and slaughter traits. Archive animal breeding, 52: 205-211.

[22] El-Bayomi, Kh.; M.; El-Tarabany, MS.; Abdel-Hamid TM, 2012. Estimation of heterosis and combining ability for some weaning and post-weaning traits in three different breeds of rabbits. Journal of American Science, 8: 282-288.

[23] Akinsola OM, Nwagu BI, Orunmuyi M, Iyeghe-Erakpotobor GT, Abanikannda OTF, 2014. Factors influencing litter traits and body weight at pre-weaning ages among temperate rabbit breeds in the tropical conditions of Nigeria. Scientific Journal of Microbiology, 3: 14-18.

[24] Khalil M.H. and Al-Homidan A.H., 2014. Genetic evaluation for growth traits and thermo tolerance parameters in synthesizing program of new rabbits International Conference On Biotechnology Applications In Agriculture, Benha University, Moshtohor and Hurghada, 8-11, Egypt.

[25] Abdel-Hamid, T., M., 2015. Crossbreeding parameters for growth traits in a complete three breedsdiallel cross design of rabbits in Egypt. J. Adv. Vet. Anim. Res., 2(2): 120-127. 
[26] Abou-KhadigaG ,Saleh K., Nofal R. ndBaselga, 2008. Genetic evaluation of growth traits in a crossbreeding experiment involving line $\mathrm{v}$ and baladi black rabbits in Egypt.9thWorld Rabbit Congress - June 10-13. - Verona - Italy.

[27] Iraqi M.M., Afifi E.A., Baselga M., Khalil M.H., García M.L. 2008. Additive and heterotic components for post-weaning Growth traits in a crossing project of V-line with Gabali rabbits in Egypt. In proceedings of 9thWorld Rabbit Congress,1013 June 2008, Verona, Italy, Issued in World Rabbit Science.

[28] Youssef Y.M.K., 2004. Heritability and common litter effects estimated by an Animal Model for post-weaning growth traits in New Zealand White and Baladi Red rabbits. Egyptian J. of Rabbit Sci., 24 (1), 205-216.

[29] Majzlik I, Zavadilova, L, Mach, K, 2007. Crossbreeding parameters for growth performance of broiler rabbits. ScientiaAgriculturaeBohemica, agris.fao.org, http://agris.fao.org/agris-search/search.do?recordID=CZ2007000320. 